\title{
Traits Affecting the Resistance of Rice Genotypes to Rice Stem Borer
}

\author{
Seyedeh Zahra Hosseini (Corresponding author) \\ Department of Plant Breeding, College of Agriculture \\ Sari Agricultural Sciences and Natural Resources University, Sari, P.O.Box 578, Iran \\ Tel: 98-151-3822-5746 E-mail: Zahra.Hosseini96@yahoo.com \\ Nadali Babaeian Jelodar \\ Department of Plant Breeding, College of Agriculture \\ Sari Agricultural Sciences and Natural Resources University, Sari, P.O.Box 578, Iran \\ Tel: 98-151-3822-5746 E-mail: n.babaeiyan@umz.ac.ir \\ Nadali Bagheri \\ Department of Plant Breeding, College of Agriculture \\ Sari Agricultural Sciences and Natural Resources University, Sari, P.O.Box 578, Iran \\ Tel: 98-151-3822-5746 E-mail: Bagherinadali@yahoo.com
}

Faramarz Alinia

Department of plant pathology, Tehran, Iran

E-mail: Faramarz.Alinia@gmail.com

Taraneh Osku

Department of rice, Amol, Iran

E-mail: Taraneh_Osku@yahoo.com

\begin{abstract}
Rice is one of the most important staple food crops for more than half of the world's population. The striped stem borer [Chilo suppresalis (walker)] is one of the most devastating pests of rice, reducing yield world wide. The use of resistant cultivars remains one of the most reliable methods to pest's management. In this study the mechanism of resistance in 10 rice lines for three kinds of resistance (antixenoses, antibioses and tolerance) in greenhouse and farm were studied. The egg mass of striped stem borer on the leaf for antixenoses resistance, larva weight mean and survival percentage of larva were evaluated for antibioses resistance. Percentage of white head was used for estimation of tolerance to striped stem borer. The results showed that line of 3 had the highest egg mass, larva survival percentage, dead heart and white head and line of 5 had the highest larva weight mean. In this study line of 3 and line of 4 were the most susceptible and tolerant genotypes, respectively. Results of this study showed that by mechanism of tolerance were affected the plant height and amount of chlorophyll on antixenoses mechanism, stem diameter and number of tiller on antibioses mechanism and stem diameter.
\end{abstract}

Keywords: Resistance mechanism, Striped stem borer, Rice

\section{Introduction}

Rice is the world's most important food that supply $40 \%$ of calories required the world's population (Heinrichs, 1998). Among the many biotic and abiotic stresses that influence the yield of rice, plant pests and diseases are the most important (Heinrichs, 1998). Application of pesticides resulted many dangers including environmental contamination, pest resistant to pesticides, eliminating of fishes and poisoning of marines. 
The striped stem borer (Chilo suppressalis Walker) is a major pest if it isn't controlled. Larva of striped stem borer goes into the plant stems and feed on plant nutrients causing. Severe crop loss (Beevor et al. 1990). Rice plants are most prone to stem borer infestation at the tillering and flowering stages (Viajante \& Heinrichs 1987). Therefore, efforts to find resistant varieties to this pest are very important. The mechanism of tolerance depends on many factors that time and environmental conditions are more important and effective. Resistance to stem borers appears to be under polygenic control (Khush, 1984). Many morphological, anatomical, physiological and biochemical factors have been reported to be associated with resistance, each controlled by different sets of genes (Chaudhary et al., 1984). Research on rice resistance to stem borers has been concerned mainly with the striped borer (Chilo suppressalis) and the yellow stem borer (Scirpophaga incertulas). Several high yielding cultivars with multiple resistances to these insects have been developed and used in the rice production systems in many parts of the world.

This research has been conducted to investigate of sensitivity and tolerance of cultivars and new improvement promising lines to striped stem borer and investigation of correlations of insect resistance with morphological characteristics of the plants.

\section{Materials and methods}

For assessment of the sensitivity and or tolerance of some cultivars and new promising lines of rice to striped stem borer, the seeds of them were sown in the nursery, separately (Table 1). Seedlings were transplanted 30 days after sowing in the plastic pot with $38 \mathrm{~cm}$ diameter. The experiment was conducted in a completely randomized design with three replications. This experiment was performed at research station of Sari Agricultural science and Natural Resources University Sari, Iran at 2008.

For evaluation of antibiosis, infestation of 45 days tillers by placing two youngest larva on the leaf for each tiller was done. After 20 days, larva and pupa in these stems were recorded. The weight and survival percentage was calculated by following formula:

$$
\text { survival percent }=\frac{\text { total living larva or pupa }}{\text { total larva used inefestion }} \times 100
$$

For evaluation of antixnosis, the egg mass recorded three days after infection by adult butterfly and the number of egg groups and number of each group on the each genotypes were compared with each other.

For evaluation of tolerance, after 40 days, two larvas were placed on each tiller. Sampling was conducted after 7 , 14 and 28 days and the amount of white head were recorded at the time of harvesting.

Finally, the percentage of impression of effective performance was calculated by following formula:

$$
\text { Im pression percentage }=\frac{\text { conta } \text { min ated plant yeild }- \text { control plant yeild }}{\text { control plant yeild }} \times 100
$$

Also, the characteristics such as stem height stem diameter, tiller number, number of panicle, length and width of leaf, length and width of flag leaf in different stages of growth were measured and its relationship with egg mass and percentage of survival, dead heart and whitehead were studied. Data analysis carried out using SAS statistic package and SPSS software.

\section{Results}

There were significant differences among the genotypes for characters $(P=0.01)$. In Table 2 means of traits classified using Duncan's multiple range test $(\mathrm{P}=0.01)$. The highest egg mass, larva weight mean, survival percentage, dead heart, white head and infestation were produced on lines 3 and 7 . These traits were least in line of 4 . Line of 3 had the highest stem diameter $(\bar{x}=7.43 \mathrm{~mm})$ and highest leaf chlorophyll, but line of 4 had the least stem diameter $(\bar{x}=4.41 \mathrm{~mm})$.

Line of 3 produced the highest average of unfilled grain and percentage of decrease of yield. But line of 4 produced the least average of unfilled grain and percentage of effective performance. Therefore lines of 3 and 7 were determined as sensitive line and line of 4 as tolerant line in this study.

Results of stepwise regression analysis showed that two traits such as survival percentage in positive direction and leaf chlorophyll in negative direction explained 64.3 percent of total egg mass variation (Table 3). Also results of stepwise regression analysis showed that five traits such as plant height, flag leaf width, infestation, 
number of tiller and leaf chlorophyll are important and explained 86.6 percent of total larva weight mean variation (Table 4). And stepwise regression analysis indicated that three traits such as egg set, stem diameter and whitehead explained 88.1 percent of total survival variation (Table 5).

The stepwise regression for egg mass as dependent variable showed that survival percentage in positive direct and chlorophyll in negative direct are important (Table 3).

There were significant positive correlation between plant height with larva weight $\left(\mathrm{r}=0.73^{* *}\right)$ and egg mass $(\mathrm{r}=$ $\left.0.38^{*}\right)$ (Table 7). Also, there were significant negative correlation between larva weight and tiller number $(\mathrm{r}=$ $\left.-0.45^{*}\right)$ and significant positive correlation between survival percentage and stem diameter $\left(\mathrm{r}=0.76^{* *}\right)$. The highest percentage of survival observed in line of $3(\bar{x}=89.17 \%)$ and Tarom cultivar $(\bar{x}=88.29 \%)$, respectively and the lowest survival percentage observed in line of $4(\bar{x}=38.30 \%)$.

The survival percentage showed positive correlation with stem diameter at $1 \%$ probability level. With increasing larva feeding of plant stem, larva survival percent has been increased and yield of plant has been reduced to same ratio. Survival percent showed significantly positive correlation with dead heart $\left(\mathrm{r}=0.698^{* *}\right)$ and white head $\left(\mathrm{r}=0.53^{* *}\right)$. The results of stepwise regression analysis showed that high spacing consequently increasing in stem diameter cause more larva survival rate due to more feeding (Table 5). The highest dead heart observed in line of $3,(\bar{x}=92.33 \%)$ and the lowest observed in line of $4(\bar{x}=1.66 \%)$. The highest white head seen in line of $3(\bar{x}=89.17 \%)$ and the lowest of it observed in line of 4 that this difference can be result of stem diameter ratio. With increasing in stem diameter, feeding rate of larva from stems had been increased and consequently dead heart has been occurred.

The results of correlation study in Table 6 indicate that dead heart and white head had positive correlation with width of leaf $(\mathrm{P}=0.01)$. Butterfly of stem borer prefer lines with thick leaf for hatch ring and consequent larva development. Also dead heart with stem diameter showed positive correlation $(\mathrm{P}=0.01)$.

According to results of farming experiment, there was significant positive correlation between contamination percentage of white head and stem diameter $(\mathrm{P}=0.05)$ and the percentage of white head with contamination percentage $(\mathrm{P}=0.01)$.

\section{Discussion}

Some of morphological characteristics in plants may act as deterrent against insect (Nouri Ganbalani et al, 1995). Rice genotypes with lower plant height, higher tiller and thinner stem diameter such as line of 4 will be tolerant against striped stem borer, because thin stem diameter characters dose not allow larva to feeding of plant (Panda et al., 1975; Khan et al., 1986; Saxena, 1986). It means, with increasing stem diameter, percentage of contamination has increased. The larva prefers thick stems for feeding because they have more space and better case. The result of this experiment agrees with the results of Saeb and Osku (2003).According to results of this study, about antixnosis resistance, cultivars and lines which had more chlorophyll and high plant height such as line of 3 was preferred for hatch ring. In antibiosis mechanism, cultivars and lines that had thick stem such as line of 3 causes to high larva weight and survival percentage result in increasing of dead heart and white head. In tolerance mechanism, cultivars and lines with more leaf length, flag leaf width and stem diameter had high white head and the mean of unfilled seeds.

By considering the results of this research we recommend that for production of tolerant cultivars against stem borer some of characteristics such as short stature, increased tiller number, reduced stem diameter and thin leaf width should be considered. There is not completely resistance cultivars against strip stem borer, but by breeding methods can be obtained cultivars and lines that stem borer larva do not able living on them.

\section{Acknowledgments}

We thank the Sari Agricultural Sciences and Natural Resources University for supporting of this project.

\section{References}

Beevor, P. S., David, H \& Jones, O.T. (1990). Female sex pheromones of Chilo spp. (Lepidoptera: Pyralidae) and their development in pest control applications. Insect Sci. Appl., 11: 787-794.

Burton, A., Malvar, R. A., Velasco, P., Revilla, P \& Ordas, A. (1998). Defense mechanisms of maize against pink stem borer. Crop Sci., 38: 1159-1163.

Chaudhary, R.C., Khush, G.S., \& Heinrichs, E.A. (1984). Varietal resistance to rice stem-borers in Asia. Insect Sci. Appl., 5: 447-463. 
Heinrichs, E. A. (1998). Management of rice insect pests. Department of Entomology, University of Nebraska. Lincln, Nebraska 816 pp.

Khan, Z. R. \& R. C. Saxena. (1986). Effect of steam distillate extracts of resistant and susceptible rice cultivars on behavior of Sogatella furcifera (Homoptera:Delphacidae). J. Econ. Entomol, 79: 928-935.

Khush, G.S. (1984). Breeding rice for resistance to insects. Protection Ecol., 7: 147-165.

Noure Ganbalani, A. H., M. F. Hosseini \& Yaghmaee. (1995). Plant resistance to insects (translation). Mashhad University Publishing Jahad. P. 262.

Osku, T. (2000). Effective factors in increasing resistance to host rice stem borer. Publishing Research Institute of Rice, Deputy of Mazandaran. P. 12.

Panda, N., B. Pradhen, A. P. Samalo \& P. S. P. RAO. (1975). Note on the relationship of some biochemical factors with the resistance in rice varieties to yellow rice stem borer. Indian J. Agric. Sci., 45:499-501.

Saeb \& T, Osku. (2004). Factors Affecting the Resistance of rice cultivars to rice stem borer. Publication of Rice Research Institute. P. 40

Saxena, R.C. (1986). Biochemical bases of insect resistance in rice varieties. In: Natural resistance of Plants to pests: Roles of Allelochemicals. ACS Symposium Series, 142-159.

Viajante, V. \& Heinrichs, E.A. (1987). Plant age effects of rice cultivar IR46 on the susceptibility to the yellow stem borer Scirpophaga incertulas (Walker) (Lepidoptera: Pyralidae). Crop. Prot., 6: 33-37.

Table 1. Name of promising lines and cultivars studied in this experiment

\begin{tabular}{|l|l|}
\hline Lines name & Lines name \\
\hline Line $1[($ IR58025A/R2) $/$ Spidrood) $]$ & Line $6($ Sange-tarom $\times$ Dasht $)$ \\
\hline Line $2[($ IR58025A/R9) $/$ Spidrood) $]$ & Line $7($ Sange-tarom $)$ \\
\hline Line $3($ Sange Tarom $\times$ Deylamani) & Line $8($ Hasani $\times$ IRRI-2) \\
\hline Line $4($ Fajr $\times$ Nok-Siyah $)$ & Line $9($ Neda $)$ \\
\hline Line 5 (IRRI-2 $\times$ Nok-Siyah) & $\begin{array}{l}\text { Line } 10(\text { Daei-shastak } \times \\
\text { Deylamani })\end{array}$ \\
\hline
\end{tabular}

Table 2. Means of the estimated traits for 10 lines in greenhouse

\begin{tabular}{|c|c|c|c|c|c|c|c|c|c|c|}
\hline $\begin{array}{l}\text { traits } \\
\text { Lines }\end{array}$ & Egg mass & $\begin{array}{l}\text { Larva } \\
\text { mean } \\
\text { weight }\end{array}$ & $\begin{array}{c}\text { Survival } \\
\text { percentage }\end{array}$ & $\begin{array}{l}\text { Dead } \\
\text { heart }\end{array}$ & $\begin{array}{l}\text { White } \\
\text { head }\end{array}$ & $\begin{array}{c}\text { Stem } \\
\text { diameter }\end{array}$ & $\begin{array}{c}\text { Average } \\
\text { unfilled } \\
\text { grain }\end{array}$ & $\begin{array}{l}\text { Leaf } \\
\text { chlorophyll }\end{array}$ & Infestation & $\begin{array}{l}\text { Decrease of } \\
\text { yield }(\%)\end{array}$ \\
\hline 1 & $11.9 \mathrm{~cd}$ & $81.66 \mathrm{bc}$ & $55.66 \mathrm{c}$ & $16.66 \mathrm{de}$ & $55.66 \mathrm{c}$ & $6.14 \mathrm{e}$ & $12.12 \mathrm{ef}$ & $42.16 \mathrm{~b}$ & $52.10 \mathrm{~cd}$ & $19.07 \mathrm{bc}$ \\
\hline 2 & $12.40 \mathrm{ab}$ & $68.0 \mathrm{c}$ & $78.94 \mathrm{~b}$ & $8.33 \mathrm{def}$ & $78.94 \mathrm{~b}$ & $6.42 \mathrm{c}$ & $8.46 \mathrm{fg}$ & $34.36 \mathrm{~d}$ & $55.30 \mathrm{bcd}$ & $15.0 \mathrm{c}$ \\
\hline 3 & $12.53 \mathrm{a}$ & $74.66 \mathrm{bc}$ & $89.17 \mathrm{a}$ & $92.33 \mathrm{a}$ & $89.17 \mathrm{a}$ & $7.43 \mathrm{a}$ & $94.69 \mathrm{a}$ & $37.80 \mathrm{c}$ & $66.37 \mathrm{a}$ & $90.50 \mathrm{a}$ \\
\hline 4 & $10.70 \mathrm{~d}$ & $50.0 \mathrm{de}$ & $38.30 \mathrm{~d}$ & $1.66 \mathrm{f}$ & $30.38 \mathrm{~d}$ & $4.41 \mathrm{~h}$ & $3.61 \mathrm{~g}$ & $36.13 \mathrm{~cd}$ & $58.09 \mathrm{bc}$ & $9.49 \mathrm{c}$ \\
\hline 5 & $11.46 \mathrm{bcd}$ & $113.33 \mathrm{a}$ & $58.88 \mathrm{c}$ & $14.66 \mathrm{de}$ & $58.88 \mathrm{c}$ & $5.52 \mathrm{f}$ & $13.92 \mathrm{e}$ & $46.96 \mathrm{a}$ & $61.53 \mathrm{ab}$ & $6.89 \mathrm{c}$ \\
\hline 6 & $12.19 \mathrm{ab}$ & $97.0 \mathrm{ab}$ & $61.77 \mathrm{c}$ & $20.0 \mathrm{~d}$ & $61.77 \mathrm{c}$ & $5.46 \mathrm{f}$ & $25.86 \mathrm{~d}$ & $26.80 \mathrm{e}$ & $47.62 \mathrm{~d}$ & $16.78 \mathrm{c}$ \\
\hline 7 & $12.33 \mathrm{ab}$ & $97.0 \mathrm{ab}$ & $88.29 \mathrm{a}$ & $55.0 \mathrm{~b}$ & $88.29 \mathrm{a}$ & $6.26 \mathrm{~d}$ & $47.97 \mathrm{c}$ & $45.83 \mathrm{a}$ & $53.5 \mathrm{bcd}$ & $29.28 \mathrm{bc}$ \\
\hline 8 & $11.76 \mathrm{abc}$ & $80.0 \mathrm{bc}$ & $54.55 \mathrm{c}$ & $35.0 \mathrm{c}$ & $54.55 \mathrm{c}$ & $5.31 \mathrm{~g}$ & $48.42 \mathrm{c}$ & $37.30 \mathrm{c}$ & $52.19 \mathrm{~cd}$ & $53.33 \mathrm{~b}$ \\
\hline 9 & $11.43 \mathrm{bcd}$ & $65.0 \mathrm{~cd}$ & $61.79 \mathrm{c}$ & $6.33 \mathrm{e}$ & $61.79 \mathrm{c}$ & $6.53 \mathrm{~b}$ & $5.68 \mathrm{~g}$ & $45.63 \mathrm{a}$ & $48.43 \mathrm{~d}$ & $17.77 \mathrm{bc}$ \\
\hline 10 & $11.16 \mathrm{~cd}$ & $57.66 \mathrm{~cd}$ & $58.48 \mathrm{c}$ & $20.33 \mathrm{~d}$ & $58.48 \mathrm{c}$ & $6.54 \mathrm{~b}$ & $54.39 \mathrm{~b}$ & $34.70 \mathrm{~d}$ & $55.40 \mathrm{bcd}$ & $25.75 \mathrm{cb}$ \\
\hline
\end{tabular}

In each column, any two means having a common letter are not significant at $\mathrm{p}=0.05$ based on Duncan's multiple range test. 
Table 3. Stepwise regression analysis for egg mass of striped stem borer

\begin{tabular}{|l|c|c|c|c|}
\hline \multicolumn{1}{|c|}{ Variable added to model } & Model parameter & Relative $\mathrm{R}^{2}$ & Accumulation $\mathrm{R}^{2}$ & $\mathrm{~F}$ \\
\hline $\mathrm{X}_{1}$ (Survival percentage) & 0.806 & 0.592 & 0.592 & $40.678^{* *}$ \\
\hline $\mathrm{X}_{2}$ (Leaf chlorophyll) & -0.276 & 0.051 & 0.643 & $27.076^{* *}$ \\
\hline
\end{tabular}

**; Significant at $\mathrm{P}=0.01$ level, based on F-test.

Table 4. Stepwise regression analysis for larva means weight of striped stem borer

\begin{tabular}{|l|c|c|c|c|}
\hline Variable added to model & Model parameter & Relative $\mathrm{R}^{2}$ & Accumulation $\mathrm{R}^{2}$ & $\mathrm{~F}$ \\
\hline $\mathrm{X}_{1}$ (Plant height) & 0.313 & 0.535 & 0.535 & $32.206^{* *}$ \\
\hline $\mathrm{X}_{2}$ (Flag leaf width) & -0.652 & 0.134 & 0.669 & $27.30^{* *}$ \\
\hline $\mathrm{X}_{3}$ (Infestation) & -0.370 & 0.072 & 0.741 & $24.84^{* *}$ \\
\hline $\mathrm{X}_{4}$ (Number of Tiller) & -0.370 & 0.078 & 0.819 & $28.34^{* *}$ \\
\hline $\mathrm{X}_{5}$ (Leaf chlorophyll) & 0.229 & 0.050 & 0.869 & $31.897^{* *}$ \\
\hline$y=236.60+0.313 x_{1}-0.652 x_{2}-0.370 x_{3}-0.37 x_{4}-0.229 x_{5}$ \\
\hline
\end{tabular}

**; Significant at $\mathrm{P}=0.01$ level, based on F-test.

Table 5. Stepwise regression analysis for the percentage of survival of striped stem borer

\begin{tabular}{|l|c|c|c|c|}
\hline Variable added to model & Model parameter & Relative $\mathrm{R}^{2}$ & Accumulation $\mathrm{R}^{2}$ & $\mathrm{~F}$ \\
\hline $\mathrm{X}_{1}$ (Egg set) & 0.393 & 0.592 & 0.592 & $6.678^{* *}$ \\
\hline $\mathrm{X}_{2}$ (Stem diameter) & 0.541 & 0.204 & 0.796 & $52.749^{* *}$ \\
\hline $\mathrm{X}_{3}$ (White head) & 0.319 & 0.085 & 0.881 & $64.40^{* *}$ \\
\hline & $y=-110.86+0.393 x_{1}+0.541 x_{2}+0.319 x_{3}$ & \\
\hline
\end{tabular}

**; Significant at $\mathrm{P}=0.01$ level, based on F-test.

Table 6. Comparison of the mean characteristics in various lines in greenhouse and farm condition

\begin{tabular}{|c|c|c|c|c|}
\hline \multirow{2}{*}{$\begin{array}{c}\text { Media } \\
\text { genotypes }\end{array}$} & \multicolumn{2}{|c|}{ farm } & \multicolumn{2}{c|}{ Greenhouse } \\
\cline { 2 - 5 } & infestation & whitehead & infestation & whitehead \\
\hline 1 & $64.06 \mathrm{c}$ & $44.05 \mathrm{c}$ & $52.10 \mathrm{~cd}$ & $55.66 \mathrm{c}$ \\
\hline 2 & $64.22 \mathrm{c}$ & $21.50 \mathrm{f}$ & $55.30 \mathrm{bcd}$ & $78.94 \mathrm{~b}$ \\
\hline 3 & $71.74 \mathrm{a}$ & $100.0 \mathrm{a}$ & $66.37 \mathrm{a}$ & $89.17 \mathrm{a}$ \\
\hline 4 & $27.83 \mathrm{~h}$ & $5.04 \mathrm{~g}$ & $58.09 \mathrm{bc}$ & $30.38 \mathrm{~d}$ \\
\hline 5 & $56.01 \mathrm{e}$ & $52.08 \mathrm{~b}$ & $61.53 \mathrm{ab}$ & $58.88 \mathrm{c}$ \\
\hline 6 & $46.55 \mathrm{~g}$ & $26.88 \mathrm{e}$ & $47.62 \mathrm{~d}$ & $61.77 \mathrm{c}$ \\
\hline 7 & $67.89 \mathrm{~b}$ & $32.25 \mathrm{~d}$ & $53.50 \mathrm{bcd}$ & $88.29 \mathrm{a}$ \\
\hline 8 & $51.34 \mathrm{f}$ & $26.70 \mathrm{e}$ & $52.19 \mathrm{~cd}$ & $54.55 \mathrm{c}$ \\
\hline 9 & $58.68 \mathrm{de}$ & $54.22 \mathrm{~b}$ & $48.67 \mathrm{~d}$ & $61.79 \mathrm{c}$ \\
\hline 10 & $59.73 \mathrm{~d}$ & $20.15 \mathrm{f}$ & $55.41 \mathrm{bcd}$ & $58.48 \mathrm{c}$ \\
\hline
\end{tabular}

In each column, any two means having a common letter are not significant at $\mathrm{p}=0.05$ based on Duncan's multiple range test. 
Table 7. Coefficient of correlation between traits of rice genotypes under greenhouse condition

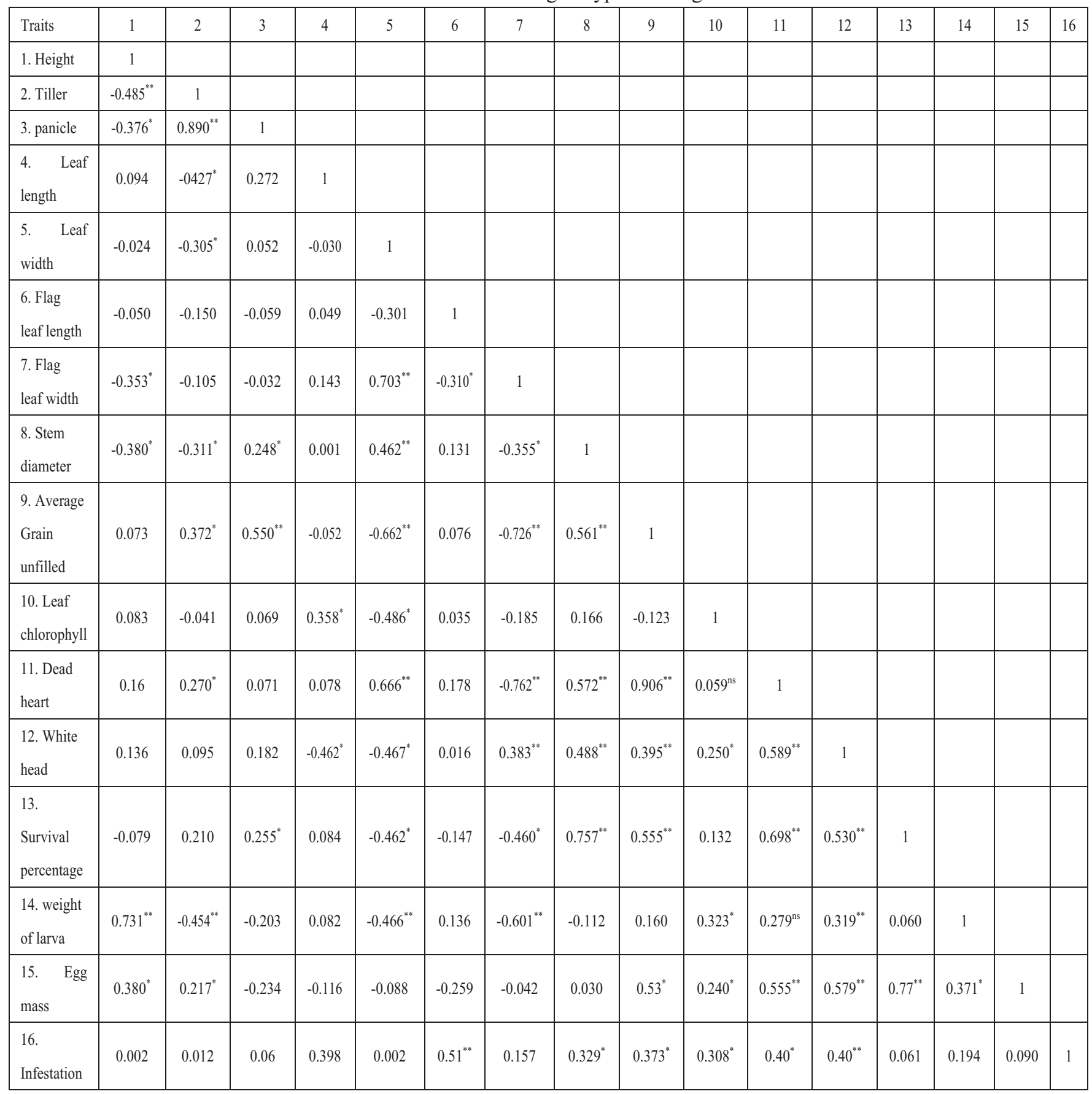

*, **; Significant at $\mathrm{P}=0.05$ and 0.01 levels, based on F-test, respectively. ns: non-significant. 